\title{
The Concurrent Roles of Self Esteem and Social Support as Mediators between Personality and Life Satisfaction
}

\author{
Hawa Rahmat, Yuen Yee Yen, Rohaidah Mashudi, Maizatul Azila Chee Din, Nur Ruziani Ishak, Chong Oi Leng
}

\begin{abstract}
The study seeks to discover the concurrent mediating effect of self-esteem and social support between personality traits and life satisfaction. A Structural Equation Modelling (SEM) was performed to determine the model of relationship on personality, social support, self-esteem, and life satisfaction. The Confirmatory Factor Analysis (CFA) has achieved the fitness index requirement on the measurement model. The results show that Personality significantly affects Life Satisfaction. The result for Social Support shows it was partially mediated the relationship between Personality and Life Satisfaction. The result also shows that Self-Esteem partially mediates the relationship between Personality and Life Satisfaction. By understanding their life satisfaction; it can forecast and promote longevity, survival and suicide risk prevention; it may accordingly promote good health and greater academic success among the students. In turn, it contributes to the existing body of knowledge in the area of SWB, specifically the life satisfaction among students in Malaysians universities. The administrator, academicians, counsellors, and parents are the group of people that benefit a lot on the outcome of this study.
\end{abstract}

Keywords - mediation, life satisfaction, personality traits, selfesteem, social support

\section{Introduction}

There were numerous studies on the topic of Subjective Well-Being (SWB) (Diener, Scollon, Lucas, 2009). According to Tov and Diener (2009), SWB is composed of people's evaluations of their lives, including pleasant affect, infrequent unpleasant affect, and life satisfaction. The term subjective well-being, happiness, satisfaction with life, and quality of life has been used interchangeably (Diener, Scollon, Lucas, 2009; Pavot and Diener, 2008; Baumeister et al. 2003; Ventegodt, Merrick, \& Andersen, 2003). Life satisfaction is the cognitive component of SWB that means a judgemental process as expressly stated by Pivot and Diener (1993) as "a conscious cognitive judgment of one's life in which the criteria for judgment are up to the person" (p.102).

Many studies across gender, age and culture have identified that personality plays a major role in influencing the people's life satisfaction. In the study of Onyishi, Okongwu, and Ugwu (2012), the analyses showed that personality is a significant predictor of life satisfaction with specification on extraversion, agreeableness, conscientiousness, and neuroticism.

\section{A. Literature Review}

Personality per says may not be crucial enough to see the impact on people's life satisfaction. There must be some underlying factors of personality that influence people's life satisfaction. For instance, changes in the life domain such as an individual that was unemployed and become employed might increase his or her judgment on life satisfaction. Life satisfaction judgment might also affect by the changes in another life domain such as employment or married (Stubbe et al., 2005; Pavot and Diener, 2008; Hayes and Joseph, 2003). In other words, life satisfaction or dissatisfaction could be caused by the external or internal factors in the relationship that might offer some insight or change the direction of the primary relationship. Henceforth, the external factor such as social support might play a vital role in affecting the direction of the relationship between personality and life satisfaction as shown in the study of Okongwu, and Ugwu (2013). Their study revealed that social support is positively related to the life satisfaction of friends, significant others, and family members were important predictors of life satisfaction among the Nigerian prison officers. Apparently, social support refers to the perception or experience that one is loved and cared for, esteem and valued, and part of a social network of mutual assistance and obligations (Wills, 1991). The study indicates the importance of social support for an individual to attain satisfaction in life.

In a study by Kong, Zhao, and You (2012) revealed that social support and self-esteem concurrently affect the relationship between emotional intelligence (EI) and life satisfaction. But EI is not purely personality trait. It is located at the lower-levels of personality hierarchies (Kong, Zhao, and You, 2012). Therefore, the current study would seek to discover personality trait with the concurrent mediation of social support and self-esteem on life satisfaction of Malaysian undergraduates. Would similar results be revealed and bring new insight into the field of SWB when the study is replicated using a different independent variable? In other words, the study will see how the personality may affect the relationship with life satisfaction and how the self-esteem and social support concurrently mediate the relationship.

Furthermore, in this study, the focus is on the young adult especially the undergraduates; a population that needs more attention as a leader for our new generation. For the students, life in the campus offers various significant opportunities and challenges with regards to their personal development. They have to make important decisions that will affect their longterm futures, i.e. career, friendships, romantic relationships, and family relations (Stevic and Ward, 2008). However, they were exposed to significant pressure, such as fine-tuning to a novel environment, changes in social groups, and struggled to meet deadlines, while maintains to keep track with their goals and future (Zullig, Ward, \& Horn, 2006). They are a 
population who frequently experience a high level of stress (Towbes and Cohen, 1996, Darling, Mcwey, Howard, \& Olmstead, 2007) in their life. On the contrary, Borrello (2005) found out that those college students who reported higher levels of SWB at the beginning of a semester experienced significantly greater academic success at the end of their study. In light of this issue, Koivumaa Honkanen, et al. (2001) also advocated that life satisfaction is prophetic of reduced suicide risk. Moreover, Lyubomirsky, King, and Diener (2005) further emphasize that life satisfaction predicts longevity, physical health, and survival.

It is evidently demonstrated that more studies on personality and related constructs such as social support, and self-esteem have to be enunciated to gauge the impact on students' life satisfaction. Therefore, it is imperative to study these constructs to investigate which one has direct or indirect relationships with life satisfaction.

Hawa Rahmat, Yuen Yee Yen, Rohaidah Mashudi, Maizatul Azila Chee Din, Nur Ruziani Ishak, Chong Oi Leng

Multimedia University

Malaysia

\section{B. Research Question}

To expand the statement of problem, the following research questions need to answer:

i. Does the personality give an impact to the life satisfaction of the Malaysian undergraduates?

ii. Does the personality provide an impact to the social support and self-esteem among the Malaysian undergraduates?

iii. Do the social support and self-esteem give an impact on the life satisfaction among the Malaysian undergraduates?

iv. Do the social support and self-esteem mediate the relationship between personality and life satisfaction among the Malaysian undergraduates?

\section{Objective(s) of the Research}

The study would seek to discover the concurrent mediation of social support and self-esteem between the relationship of personality and life satisfaction among Malaysian universities students. Specifically, the objectives of the research are:

i. To investigate the impact of personality on life satisfaction among the undergraduates.

ii. To examine the impact of personality on social support and self-esteem among the undergraduates.

iii. To inspect the impact of social support and self-esteem on life satisfaction among the undergraduates

iv. To explore the mediating effects of social support and self-esteem between the personality and life satisfaction among the undergraduates.

\section{A. Conceptual Framework}

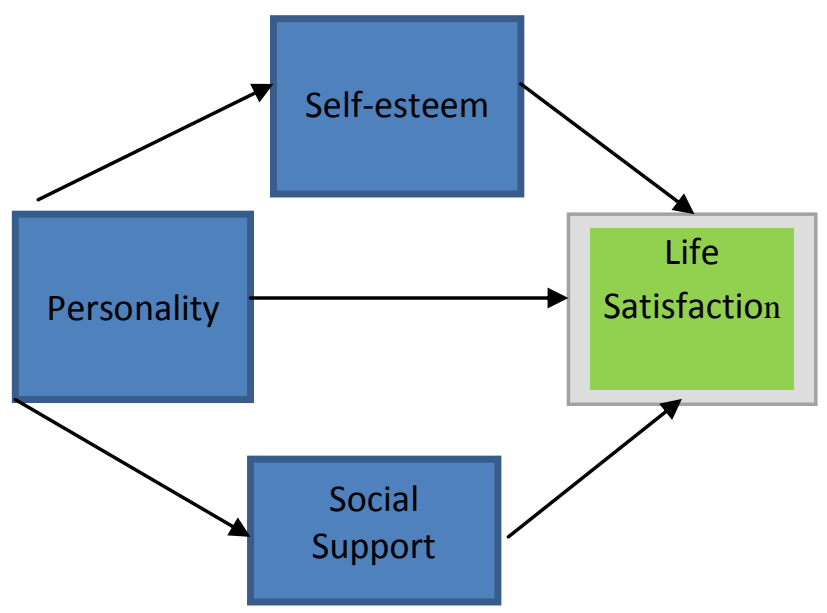

Figure 1. Conceptual framework on the model of relationship on personality, social support, self-esteem, and life satisfaction.

\section{B. Methodology}

The present research is quantitative in nature. It utilized a cross-sectional correlational study method by using survey design with validated questionnaires. A cross-sectional study has its advantage whereby a large number of questionnaires were distributed to a large number of populations in a short period as intended in the study.

Population, Sample, and sampling: The populations understudied are students from the diverse socio-demographic background in the Malaysian universities.

Due to limited time and budget, only private universities become the sample for the study. The universities were clustered based on region. The Central region is chosen due to its most private university are is the Central region.

Simple random sampling was applied to choose the universities in the central region to be involved in the study. After running the simple random sampling, three universities are selected, i.e., MMU, UNITAR, and UNITEN to represent the private universities. 320 local students from the three private universities were involved in the study. Then, the respondents in each university were clustered into faculty. Respondents were selected based on every count of five people that the researcher met in each faculty.

\section{Instruments:}

i. An instrument for socio-demographic factors was developed based on the literature review and research questions. 
ii. Life Satisfaction - Satisfaction with Life Scale (SWLS). Five items of SWLS by Diener, Emmans, Larsen, \& Griffin (1985) measures people overall judgment of their satisfaction with life. A Higher score indicates the high life satisfaction. A lower score indicates low life satisfaction. The scoring is using 7-point Likert scale ranging from strongly disagree (1) to strongly agree (7).

iii. Personality - Eight items were adapted from the International Personality Item Poll (IPIP) (Goldberg, 1992) to measure personality.

iv. Social Support - Multi-Dimensional Scale of Perceived Social Support (MSPSS). The MSPSS (Zimet, Dahlem, Zimet, \& Farley, 1988) consists of 12-items relating to perceived social support. Three separate scores can be calculated for the sources of support such as significant others, family, and friends. Higher scores indicate greater perceived social support.

v. Self-esteem - The Rosenberg self-esteem scale (RSES). The RSES is a 10-item self-report measure of global self-esteem (Rosenberg, 1985). Items rated from 1 (strongly disagree) to 4 (strongly agree). Scale scores are the sum of items with the reverse coding of relevant items.

Pre-test and pilot test: The pre-test was done to examine the validity of the content of the questionnaire. The questionnaires were adapted from the established scales. Hence, some items were omitted to suit the current research. In the pre-test, 30 students were randomly selected to answer the revised questionnaire. After the pre-test, a pilot test was conducted to 107 students with random selection. Exploratory Factor Analysis (EFA) was conducted, and reliability using Cronbach alpha for each scale showed above 0.7 as shown in Table 1.

Table 1. Reliability with Cronbach alpha

\begin{tabular}{|c|c|c|}
\hline Scales & Item & Reliability \\
\hline Satisfaction with Life Scale & 4 & .840 \\
\hline Personality & 8 & .720 \\
\hline Rosenberg Self-Esteem & 4 & .719 \\
\hline $\begin{array}{l}\text { Multidimensional Scale o } \\
\text { Perceived Social Support }\end{array}$ & 12 & .962 \\
\hline
\end{tabular}

\section{Data Analysis}

A Descriptive and Structural Equation Modelling (SEM) were performed to address the particular research question. Data were analysed using SPSS and AMOS. This study conforms to Anderson and Gerbing (1988) of SEM technique in specifying the interdependence quality relationships among the latent variables as the measurement models, as shown in Figures 2. This study also follows Bagozzi and Yi (2012), in which they suggest careful consideration of the magnitude of the factor loadings and modification indices, with appropriate justifications to improve the model fit of the measurement model. After re-specification of the model, the standardized factor loadings for all the items on their associated items showed greater than 0.5 (Hair et al., 2009). Also, the unstandardized error variances for all items are lower than 0.60 .

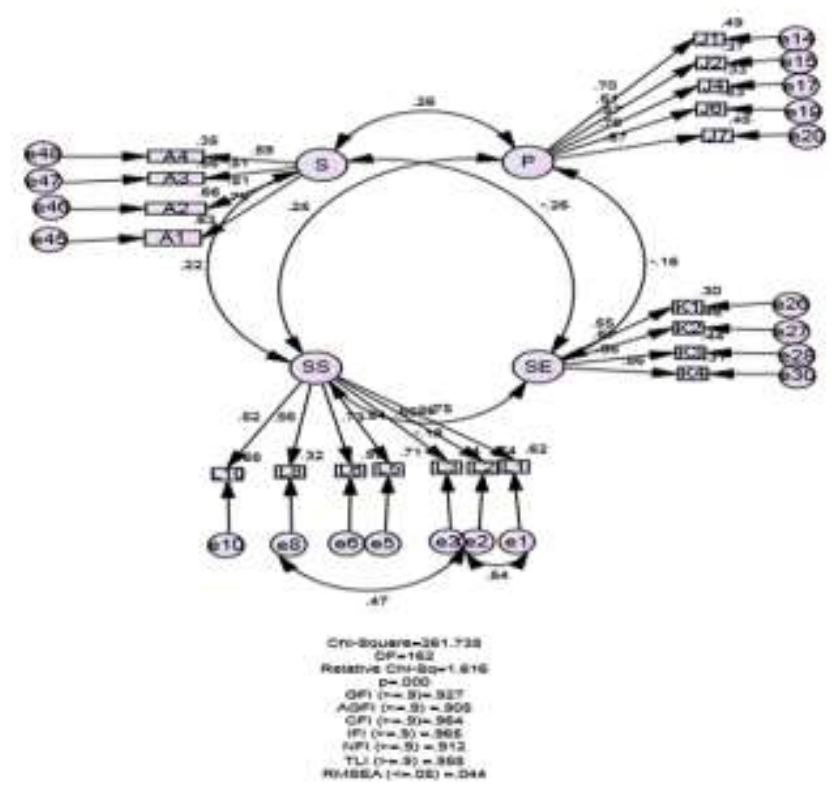

Figure 2. CFA on Measurement Model

All Composite Reliability values in the model have exceeded the cut-off criterion of 0.7 , and the convergent validity of the latent variables is verified by AVE values of equal to or greater than 0.40 (Fornell and Larcker, 1981; Hair et al., 2010).

In accordance to Anderson and Gerbing (1988), convergent validity can be assumed when the unstandardized loading estimates are significant and greater than standard error. The unstandardized loading estimates are at higher magnitude compared to the values of standard error. Specifically, the standard errors range from 0.043 to 0.104 , while the unstandardized loading estimates from 0.729 to 1.269 . The unstandardized estimates for all the items are significant at 0.001 , with the critical value ranging from 6.695 to 24.240 . Thus, convergent validity is assumed for all the constructs.

Discriminant validity involves the quality relationship between a particular latent construct and other constructs of a similar nature (Brown, 2006). Discriminant validity refers to the extent in which a construct is truly distinct from other constructs (Brown, 2006). Discriminant validity for all constructs is achieved when a diagonal square root AVE value is higher in the inter-correlation values in its row and column as shown in Table 2. 
Proc. of the Eighth Intl. Conf. on Advances in Social Science, Management and Human Behaviour - SMHB 2019

Copyright $(\odot$ Institute of Research Engineers and Doctors. All rights reserved. ISBN: 978-1-63248-168-9 DOI : 10.15224/978-1-63248-168-9-02

Table 2: Assessment of Discriminant Validity

\begin{tabular}{|c|c|c|c|c|}
\hline & $\begin{array}{l}\text { Perceived } \\
\text { Social } \\
\text { Support }\end{array}$ & Personality & $\begin{array}{l}\text { Self- } \\
\text { Esteem }\end{array}$ & $\begin{array}{l}\text { Satisfaction } \\
\text { with Life }\end{array}$ \\
\hline $\begin{array}{l}\text { Perceived } \\
\text { Social } \\
\text { Support }\end{array}$ & 0.757 & & & \\
\hline Personality & 0.253 & 0.672 & & \\
\hline \multicolumn{5}{|l|}{ Esteem } \\
\hline $\begin{array}{l}\text { Satisfaction } \\
\text { with Life }\end{array}$ & 0.220 & 0.259 & -0.258 & 0.760 \\
\hline \multicolumn{5}{|c|}{$\begin{array}{l}\text { Furthermore, among all items measuring Skewness and } \\
\text { kurtosis are less than }+-1 \text {, the reported values for both were } \\
\text { within the acceptable values of }-2.0 \text { and }+3.5 \text { (Lei and Lomax, } \\
\text { 2005), indicating that the data normally distributed. }\end{array}$} \\
\hline \multicolumn{5}{|c|}{$\begin{array}{l}\text { Structural Model: The goodness-of-fit indexes for overall } \\
\text { structural model are summarized in Table } 3 \text {. The overall } \\
\text { structural model is acceptable as at least } 3-4 \text { of the goodness- } \\
\text { of-fit indexes are within the desirable range (Hair et al. 2009). }\end{array}$} \\
\hline \multicolumn{5}{|c|}{ Table 3: Goodness of Fit for Structural Model } \\
\hline \multicolumn{2}{|c|}{ Goodness-of-Fit } & Desirable & \multicolumn{2}{|c|}{ Structural } \\
\hline \multicolumn{2}{|l|}{ Indices } & Range & \multicolumn{2}{|c|}{ Model } \\
\hline \multicolumn{2}{|l|}{ GFI } & $\geq 0.90$ & & $.920 * * *$ \\
\hline \multicolumn{2}{|l|}{ CFI } & $\geq 0.90$ & & $.956 * * *$ \\
\hline \multicolumn{2}{|l|}{$\mathrm{NFI}$} & $\geq 0.90$ & & $.904 * * *$ \\
\hline \multicolumn{2}{|l|}{ TLI } & $\geq 0.90$ & & $.950 * * *$ \\
\hline \multicolumn{2}{|c|}{ Relative chi-square } & $\leq 3.0$ & & $1.737^{* * *}$ \\
\hline \multicolumn{2}{|l|}{ RMSEA } & $\leq 0.80$ & & $.048 * * *$ \\
\hline
\end{tabular}

***-Within desirable range

\section{Results and Discussions}

320 local students from three private universities in Malaysia involved in the study. After data cleaning, no missing values detected. The age of the students ranging from 17-19 (24.4\%), 20-22 (68.1\%) and 23-25 (7.5\%). The gender ranging from $130(40.6 \%)$ males and 190 (59.4\%) females. The three main races in Malaysia ranging from Malay (56.6\%), Chinese (30.3\%), Indian (12.2\%), and others (0.9\%).
Figure 3 shows that self-esteem is the most important factor that significantly affects satisfaction with life ( standardized beta coefficient $=0.522$, p-value $=0.003$ ). Personality is the second most important factor that significantly affects satisfaction with life (standardized beta coefficient $=0.303$, $\mathrm{p}$-value $=0.002$ ). Perceived social support is the third most important factor that significantly affects satisfaction with life (standardized beta coefficient $=0.120$, pvalue $=0.013$ ). These three factors explain $11.0 \%$ of the variance in satisfaction with life.

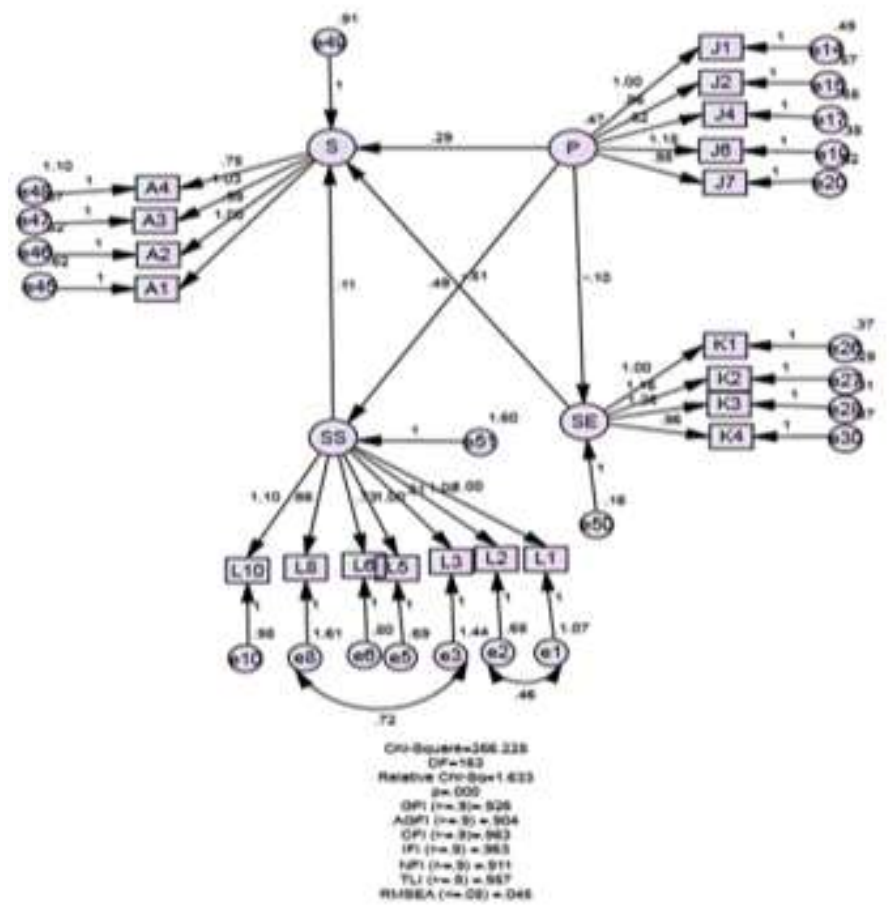

Figure 3. Structural Model

Mediation Effect: Begin with simple effect of personality (P) on life satisfaction (S) as shown in figure 4 to test the direct effect. The result shows that the direct effect is 0.303 , and it has a significant effect on life satisfaction ( $\mathrm{p}$-value = 0.002). Personality significantly affects Life Satisfaction.

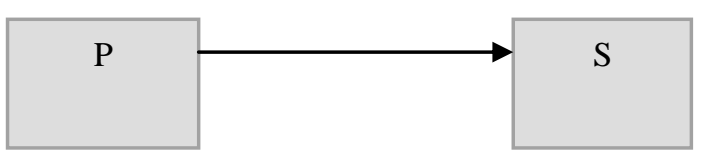

0.303

Figure 4. Modeling the direct effect of $\mathrm{P}$ on $\mathrm{S}$

Mediation was entered into the model. Self-esteem (SE) and Social support (SS) concurrently become the mediation on the relationship between $\mathrm{P}$ and $\mathrm{S}$. The outcome in Table 5 indicates that the coefficient value for the direct effect is reduced from 0.303 to 0.286 when mediation enters the model. However, the direct effect is still significant ( $p$-value $=0.006$ ). The direct effect of $\mathrm{P}$ on SE indicates the coefficient value of - 
0.099 (p-value $=0.028)$. And, the direct effect of SE on S indicates the coefficient value of -0.512 (p-value $=0.005)$. The results show that $\mathrm{P}$ has significant, and direct effect on SE and $\mathrm{SE}$ has significant and direct effect on $\mathrm{S}$. The second mediator variable was entered in the model is SS. The direct effect of $\mathrm{P}$ on SS indicates the coefficient value of 0.493 (p-value = 0.000 ). And, the direct effect of $\mathrm{SE}$ on $\mathrm{S}$ indicates the coefficient value of 0.112 (p-value $=0.025)$. The results show that $\mathrm{P}$ has significant, and direct effect on SS and SS has significant, and direct effect on S. The type of mediation is called a "partial mediation" since the direct effect of $\mathrm{P}$ on $\mathrm{S}$ is reduced but still significant after the mediation enters the model. The model of the concurrent mediation of SE and SS between $\mathrm{P}$ and $\mathrm{S}$ is shown in Figure 5.

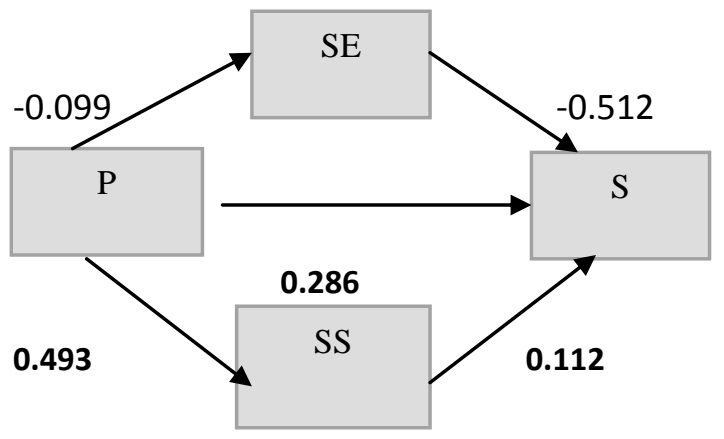

Figure 5. Modeling the concurrent mediators of SE and SS between $\mathrm{P}$ and $\mathrm{S}$

The type of mediation for both the model as shown in figure 3 and 5 is partial mediation. It explains that social support and self-esteem influence personality on the impact on life satisfaction. Personality has fundamental impact on people's life satisfaction. But self-esteem and social support influence personality on the impact on life satisfaction. Henceforth, the external factor such as social support might play a vital role in affecting the direction of the relationship between personality and life satisfaction as shown in the study of Okongwu, and Ugwu (2012). Their study revealed that social support is positively related to the life satisfaction of friends, significant others, and family members were important predictors of life satisfaction among the Nigerian prison officers. The study indicates the importance of social support for an individual to attain satisfaction in life. Selfesteem, the positive or negative orientation toward the self (Rosenberg, 1985) have reflected a sense of self-regard and self-worth that could enhance personality characteristics, which in turn, affect the life satisfaction. Furthermore, in the collectivist society like Malaysia, social support is part and partial of living in happiness and life satisfaction.

Conclusion: The results showed that more studies on personality and related constructs such as social support, and self-esteem have to be enunciated to gauge the impact on students' life satisfaction. By understanding the factors that forecast and support durability on physical health, survival and suicide risk prevention, it may accordingly promote good health and greater academic success among the students. In turn, it will contribute to the existing body of knowledge in the area of SWB, particularly on life satisfaction among students in Malaysians universities. However, the results could only generalize to private university students. Future research may embark on studying the effect on public university students.

\section{Acknowledgment}

Thank you to MMU MiniFund 2014/2015.

\section{References}

[1] Anderson, J. C. \& Gerbing, D. W.: Structural Equation Modeling in Practice: A Review and Recommended Two - Step Approach. Psychological Bulletin, 103, 3, 411 - 423 (1988)

[2] Bagozzi, R. P. \& Yi, Y.: Specification, Evaluation, and Interpretation of Structural Equation Models. Journal of the Academy of Marketing Science, 40,1, 8 - 34 (2012)

[3] Baumeister, R. F., Campbell, J. D., Krueger, J. I., \& Vohs, K. D.: Does high self-esteem cause better Performance, interpersonal success, Happiness, or healthier lifestyles? Psychological science in the public interest vol. 4, no. 1, 1-44 (2003)

[4] Borrello, A.: Subjective well-being and academic success among college students. Unpublished doctor's dissertation, Capella University (2005)

[5] Brown, T. A.: Confirmatory factor analysis for applied research. New York: Guilford (2006)

[6] Darling, C. A., Mcwey, L. M., Howard, S. N., Olmstead, S. B.: College student stress-The influence of interpersonal relationships on sense of coherence. Stress and Health, 23, 4, 215-229 (2007)

[7] Diener, E., Diener, M., \& Diener, C.: Factors predicting the subjective well-being of nations. Journal of Personality and Social Psychology, 69, 5, 851-864 (1995)

[8] Diener, E., Emmans, R. A., Larsen, R. J., \& Griffin.: The satisfaction with life scale. Journal of Personality Assessment, 49, 1 (1985)

[9] Diener, E., Scollon, C. N., \& Lucas, R. E.: The Evolving Concept of Subjective Well-Being: The Multifaceted Nature of Happiness, 39, 67100 (2009)

[10] Fornell, C., Larcker, D.F.: Evaluating structural equation models with unobservable variables and measurement error. Journal of Marketing Research 18, 1, 39-50 (1981)

[11] Goldberg, L. R.: The development of markers for the Big Five factor structure. Psychological Assessment, 4, 26-42 (1999)

[12] Hair, J.F., Black, W.C., Babin, B.J., \& Anderson, R.E.: Multivariate Data Analysis. Seventh Edition. Prentice Hall, Upper Saddle River, New Jersey (2010)

[13] Hair, J. F., Black, W. C., Babin, B. J., \& Anderson, R. E.: Multivariate data analysis. Upper Saddle River, NJ: Prentice Hall (2009)

[14] Hayes, N., and Joseph, S.: Big 5 correlates of three measures of subjective well-being. Personality and Individual Differences, 34, 4, 723-727 (2003)

[15] Koivumaa Honkanen, H., Honkanen, R., Viinamaki, H., Heikkila, K., Kaprio, J., Koskenvuo, M.: Life satisfaction and suicide-A 20-year follow-up study. The American Journal of Psychiatry, 158, 3, 433-439 (2001)

[16] Kong, F., Zhao, J., \& You, X.: Emotional intelligence and life satisfaction in Chinese university students: The mediating role of selfesteem and social support. Personality and Individual Differences 53 (8), 1039-1043 (2012)

[17] Lei, M., Lomax, R.G.: The effect of varying degrees of nonnormality in structural equation modeling. Structural Equation Modeling 12 (1), 1-27 (2005)

[18] Lyubomirsky, S., King, L., Diener, E.: The benefits of frequent positive affect-does happiness lead to success? Psychological Bulletin, 131, 6, 803-855 (2005)

[19] Onyishi, I. E., Okongwu, O. E., \& Ugwu, F. O.: Personality and social support as predictors of life satisfaction of Nigerian prisons officers. European Scientific Journal, 8, 20 (2012) 
Proc. of the Eighth Intl. Conf. on Advances in Social Science, Management and Human Behaviour - SMHB 2019

Copyright $(\odot$ Institute of Research Engineers and Doctors. All rights reserved.

ISBN: 978-1-63248-168-9 DOI : 10.15224/978-1-63248-168-9-02

[20] Pivot W., \& Diener E.: Review of the Satisfaction With Life Scale. Psychological Assessment, 5, 164-72. (1993)

[21] Pavot, W., and Diener, E.: The Satisfaction With Life Scale and the emerging construct of life satisfaction. The Journal of Positive Psychology, 3, 2, 137-152 (2008)

[22] Rosenberg, M.: Self-concept and psychological well-being in adolescence. In R. Leahy (Ed). The development of the self. New York: Academic press (1985)

[23] Stevic, C. R., Ward, R. M.; Initiating personal growth the role of recognition and life satisfaction on the development of college students. Social Indicators Research, 89, 523-534 (2008)

[24] Stubbe, J. H., Posthuma, D., Boomsma, D. I., \& De Geus, E. J. C.: Heritability of life satisfaction in adults: a twin-family study Psychological Medicine, 35, 11, 1581- 1588 (2005)

[25] Towbes, L., Cohen, L. H.: Chronic stress in the lives of college students - Scale development and prospective predictions of distress. Journal of Youth and Adolescence, 25, 199-217 (1996)

[26] Tov, M., and Diener, E.: Culture and Well-Being. Social Indicators Research, 38, 9-41(2009)

[27] Ventegodt, S., Merrick, J., \& Andersen, N. J.: Quality of Life Theory I. The IQOL Theory: An Integrative Theory of the Global Quality of Life Concept. The Scientific World Journal, 3, 1030-1040 (2003)

[28] Wills, T. A.: Social support and interpersonal relationships. Clark, Margaret S. (Ed). Prosocial behavior. Review of personality and social psychology, 12, 265-289 (1991)

[29] Zimet, G.D., Dahlem, N.W., Zimet, S.G. \& Farley, G.K.: The Multidimensional Scale of Perceived Social Support. Journal of Personality Assessment, 52, 30-41 (1988)

[30] Zullig, K. J., Ward, R. M., Horn, T.: The association between perceived spirituality, religiosity, and life satisfaction - The mediating role of selfrated health. Social Indicators Research, 79, 255-274 (2006)

About Author (s):

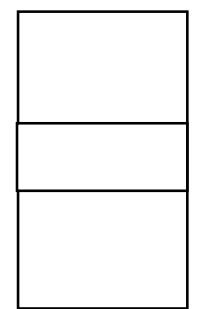

By understanding the factors that forecast and support durability on physical health, survival and suicide risk prevention, it may accordingly promote good health and greater academic success among the students. 